\title{
Gyrate atrophy of the choroid and retina associated with hyperornithinaemia
}

\author{
KIRSTI TAKKI \\ From the Department of Ophthalmology, University of Helsinki, Finland
}

The inheritance of the autosomal recessive type of gyrate atrophy of the choroid and retina seems well documented (Botermans, I972), but the aetiology of the disease is still unknown.

Animal experiments and some disturbances of lipid, carbohydrate, and protein metabolism connected with chorio-retinal degenerations in man support the possibility of an enzymatic disorder as an aetiological factor of these diseases (Franceschetti, François, and Babel, ı 963 ; François, 1964).

The present author recently diagnosed gyrate atrophy of the choroid and retina in an 8-year-old boy in whom an enlarged lysine-ornithine spot was found on the urine highvoltage electrophorogram in routine examination of urinary amino-acids. Further studies identified that the spot was ornithine. The plasma ornithine concentration was more than ten times higher than normal, although normal amounts of the other plasma aminoacids were present. A constant correlation between hyperornithinaemia and gyrate atrophy of the choroid and retina was then detected in nine other patients (Simell and Takki, 1973).

The purpose of this paper is to describe the different forms of gyrate atrophy found in a total of fifteen patients and to discuss the correlation of fundus changes with hyperornithinaemia.

\section{Material}

An examination of case histories from 1950 to 1972 , with clinical diagnosis of any primary chorioretinal degeneration, revealed some thirty cases in which gyrate atrophy was suspected. Among them eleven cases of gyrate atrophy of the choroid and retina at different stages were found. Three additional cases were found among relatives of one patient and one further case was referred to the author. The total number of cases with gyrate atrophy of the choroid and retina described in this paper is thus fifteen, nine of which were included in our previous paper (Simell and Takki, 1973). The characteristics of the patients are shown in Table I (overleaf). Among the ten families there were four sisters (Patients 6 and 9-1 I) and two pairs of sisters (Patients 3, 5, and 12-13) and one of these was the first cousin of another patient (Patient 4).

There were twenty intact and ten aphakic eyes, four of which were treated because of open-angle glaucoma. One eye was in postoperative phthisis after a cataract operation (Table II, overleaf). 
Table I Sex, age, weight, and height of patients with gyrate atrophy of the choroid and retina. Samples for amino-acid estimation are also indicated

\begin{tabular}{|c|c|c|c|c|c|c|}
\hline $\begin{array}{l}\text { Patient } \\
\text { no. }\end{array}$ & Sex & $\begin{array}{l}\text { Age } \\
(y r s)\end{array}$ & $\begin{array}{l}\text { Weight } \\
(\mathrm{kg} .)\end{array}$ & $\begin{array}{l}\text { Height } \\
(\mathrm{cm} .)\end{array}$ & $\begin{array}{l}\text { Aqueous humour } \\
\text { basic amino- } \\
\text { acids determined }\end{array}$ & $\begin{array}{l}\text { Spinal fluids } \\
\text { basic amino- } \\
\text { acids determined }\end{array}$ \\
\hline I* & $\mathrm{m}$ & 9 & $28 \cdot \mathbf{I}$ & I $36 \cdot 5$ & & \\
\hline 2 & $\mathrm{~m}$ & IO & $27^{\circ} 0$ & $\mathrm{I} 43^{\circ} \mathrm{O}$ & & \\
\hline $3^{*}$ & $\mathrm{f}$ & I3 & $43 \cdot 5$ & $143^{\circ} 0$ & + & \\
\hline $4^{*}$ & $\mathrm{~m}$ & 19 & $64 \cdot 0$ & $171 \cdot 5$ & & \\
\hline $5^{*}$ & $\mathrm{~m}$ & 26 & $47^{\circ} \mathrm{O}$ & $162 \cdot 0$ & + & + \\
\hline 6 & $f$ & 27 & $5^{8 \cdot 0}$ & $160 \cdot 0$ & & \\
\hline $7^{*}$ & $\mathrm{~m}$ & 34 & $69 \cdot 0$ & $174^{\circ} 0$ & + & + \\
\hline $8 *$ & $\mathrm{~m}$ & 36 & $64^{\circ} \mathrm{o}$ & $175^{\circ} 0$ & + & + \\
\hline 9 & $\mathrm{f}$ & 37 & $63 \cdot 0$ & $\mathrm{I} 6 \mathrm{I} \cdot 0$ & + & \\
\hline IO & $\mathrm{m}$ & 39 & $70 \cdot 1$ & $\mathrm{I} 70^{\circ} \cdot 0$ & & \\
\hline I I & $\mathrm{m}$ & 44 & $70 \cdot 0$ & $162 \cdot 0$ & + & \\
\hline $12 *$ & $\mathrm{~m}$ & 47 & $68 \cdot 5$ & $173^{\circ} 0$ & & \\
\hline $13^{*}$ & $\mathrm{~m}$ & $5^{1}$ & $60 \cdot 0$ & $180^{\circ} 0$ & + & + \\
\hline $14^{*}$ & $\mathrm{~m}$ & $5^{I}$ & $67^{\circ} \mathrm{o}$ & $172 \cdot 0$ & & \\
\hline I 5 & $\mathrm{~m}$ & $5^{I}$ & $5^{0^{\circ} \mathrm{O}}$ & $\mathrm{I} 62 \cdot 0$ & & \\
\hline
\end{tabular}

* Patient included in previous paper (Simell and Takki, 1973)

\section{Ophthalmological examination}

A routine ophthalmological examination was performed on all patients.

Visual fields were determined with the Goldmann kinetic and Friedmann perimeters.

Dark adaptation was measured with the Goldmann-Weeker's adaptometer. Classification according to the method of François, Verriest, and de Rouck (1956) was used: Type I-normal; Type II - a biphasic curve in which the segment representing the cones is normal but that representing the rods is delayed; Type III - the adaptation of the rods fails to develop; Type IV - the curve is monophasic and represents the adaptation of the foveal cones; Type V-the adaptation of the foveal cones is defective.

Colour vision was tested with the Farnsworth dichotomous test (D-I5 panel).

Electroretinography in the semi-dark adaptation state was recorded and Karpe's method (I96I) was used.

Electro-oculography was performed according to the method of Arden, Barrada, and Kelsey (1962).

Tonography was carried out with the compact model electronic tonometer (Mueller and Co.), which incorporates an Esterline-Angus recorder. Values for intraocular pressure and outflow facility were obtained from the 1955 Friedenwald calibration tables (Moses and Becker, 1958). The criteria for glaucoma of Becker and Shaffer (1970) were used.

Fluorescein angiography of the fundus was performed with a modified Zeiss Robot fundus camera. A Baird B 4 was employed as the excitation filter and with the Kodak Wratten 15 barrier filter. The film used was Kodak Tri-X Pan. The films were developed in Kodak D-76 (diluted I to I) for I $6 \mathrm{~min}$. at $20^{\circ} \mathrm{C}$. $5 \mathrm{ml}$. Io per cent. sodium fluorescein were injected rapidly into the antecubital vein. The angiography was started $6 \mathrm{sec}$. after injection and the angiograms were taken at $\mathrm{I}$ to 2 -second intervals. Late pictures were also taken at 5, 10 , and 20 minutes. Colour diapositives were taken of all subjects. 
Table II Ophthalmological characteristics in patients with gyrate atrophy of the choroid and retina

\begin{tabular}{|c|c|c|c|c|c|c|c|c|}
\hline \multirow{3}{*}{$\begin{array}{l}\text { Pat. } \\
\text { no. } \\
\mathrm{I}\end{array}$} & \multicolumn{2}{|c|}{$\begin{array}{l}\text { Corrected visual } \\
\text { acuity }\end{array}$} & \multicolumn{2}{|c|}{ Refraction (dioptres) } & \multicolumn{2}{|l|}{ Lens } & \multicolumn{2}{|c|}{$\begin{array}{l}\text { Crystals detected } \\
\text { in fundus }\end{array}$} \\
\hline & Right & Left & Right & Left & Right & Left & Right & Left \\
\hline & $I \cdot O$ & $1 \cdot 0$ & $\begin{array}{l}S-4 \cdot 0 \\
C-0 \cdot 75\end{array}$ & $\begin{array}{l}-3 \cdot 0 \\
-0.75\end{array}$ & $\begin{array}{l}\text { Almost } \\
\text { clear }\end{array}$ & $\begin{array}{l}\text { Almost } \\
\text { clear }\end{array}$ & - & - \\
\hline 2 & 0.7 & $1 \cdot 0$ & $\begin{array}{l}S-5 \cdot 50 \\
G-1 \cdot 0\end{array}$ & $\begin{array}{l}-4 \cdot 50 \\
-1 \cdot 50\end{array}$ & $\begin{array}{l}\text { Almost } \\
\text { clear }\end{array}$ & $\begin{array}{l}\text { Almost } \\
\text { clear }\end{array}$ & - & - \\
\hline 3 & 0.4 & 0.6 & $\begin{array}{l}S-6 \cdot 0 \\
C-0 \cdot 50\end{array}$ & $-4 \cdot 0$ & Cat. & Cat. & - & - \\
\hline 4 & $0 \cdot 15$ & $0 \cdot I$ & $\begin{array}{l}S-5 \cdot 0 \\
C-2 \cdot 0\end{array}$ & $\begin{array}{l}-5 \cdot 0 \\
-2 \cdot 0\end{array}$ & Cat. & Cat. & - & - \\
\hline 5 & 0.4 & $0 \cdot 2$ & $\begin{array}{l}S-6 \cdot 25 \\
C-0 \cdot 75\end{array}$ & $-7 \cdot 0$ & Cat. & Cat. & - & - \\
\hline 6 & 0.4 & 0.8 & $\begin{array}{l}\mathrm{S}+4 \cdot 50 \\
\mathrm{C}+\mathrm{I} \cdot 0\end{array}$ & $\begin{array}{l}+4.50 \\
+0.50\end{array}$ & A & A & + & + \\
\hline 7 & $0 \cdot 15$ & $0 \cdot 15$ & $S-10 \cdot 50$ & $-12 \cdot 0$ & Cat. & Cat. & - & - \\
\hline 8 & 0.6 & 0.7 & $\begin{array}{l}S-6 \cdot 0 \\
G-3 \cdot 0\end{array}$ & $\begin{array}{l}-6 \cdot 0 \\
-I \cdot 50\end{array}$ & Cat. & Cat. & - & - \\
\hline 9 & 0.5 & $0 \cdot 2$ & $\begin{array}{l}S+6 \cdot 0 \\
\mathrm{C}+\mathrm{I} \cdot 50\end{array}$ & $\begin{array}{l}+6 \cdot 0 \\
+1 \cdot 25\end{array}$ & A & A & + & + \\
\hline 10 & 0.4 & $0 \cdot 7$ & $\mathrm{~S}+5 \cdot 25$ & $\begin{array}{l}+4 \cdot 75 \\
+1 \cdot 0\end{array}$ & A & A & + & + \\
\hline I I & $0 \cdot 4$ & $0 \cdot 3$ & $\begin{array}{l}S+6 \cdot 0 \\
\mathrm{C}+2 \cdot 50\end{array}$ & $\begin{array}{l}+6 \cdot 0 \\
+3 \cdot 0\end{array}$ & A & A & + & + \\
\hline 12 & $0 \cdot 09$ & 0.03 & $\begin{array}{l}S-6 \cdot 0 \\
C-1 \cdot 0\end{array}$ & $-7 \cdot 0$ & Cat. & Cat. & + & + \\
\hline I 3 & $0 \cdot 1$ & $\begin{array}{l}\text { hand } \\
\text { movements }\end{array}$ & $S-20 \cdot 0$ & $-22 \cdot 0$ & Cat. & Cat. & + & + \\
\hline 14 & $0 \cdot 15$ & $\mathbf{I} / \infty$ & $S+7 \cdot 0$ & & A & $\begin{array}{l}\text { Phthisis } \\
\text { bulbi }\end{array}$ & + & \\
\hline 15 & $0 \cdot 09$ & 0.08 & $S-8 \cdot 0$ & $-9 \cdot 0$ & Cat. & Cat. & & \\
\hline
\end{tabular}

$\mathrm{S}=$ spherical

$\mathrm{C}=$ cylindrical

Cat. = cataract

$\mathrm{A}=$ aphakic

\section{Other clinical studies}

Electroencephalogram and neurological examination were carried out at the Children's clinic. The EEG was recorded for fourteen patients, using the method of Pampiglione (1956). In all subjects a resting EEG was registered including activation methods: eye opening and shutting, overventilation for 2.5 to 3 minutes, and photic stimulation. Oral chloral hydrate $20 \mathrm{mg}$. $/ \mathrm{kg}$. body weight was used to induce sleep. This was given 5 minutes after beginning the recording. A sleep record was obtained for three patients and a further nine were drowsy during some period of the examination.

Intelligence tests were carried out on fourteen patients by psychologists at the Children's clinic and the Institute of Occupational Health. The intelligence quotient was measured by the Wais and Wechsler intelligence scale modified by von Fieandt and Kalimo (1972) for adults and by the Wechsler Intelligence Scale (1949) for children. Special note was taken of the diminished visual acuity of the patients in the tests.

Audiological examination was performed by a consultant audiologist. Audiograms were taken of all patients and electronystagmography of six of them.

Medical examination included clinical examination, electrocardiogram, (12 leads), and routine skull and lung $x$-ray studies. 

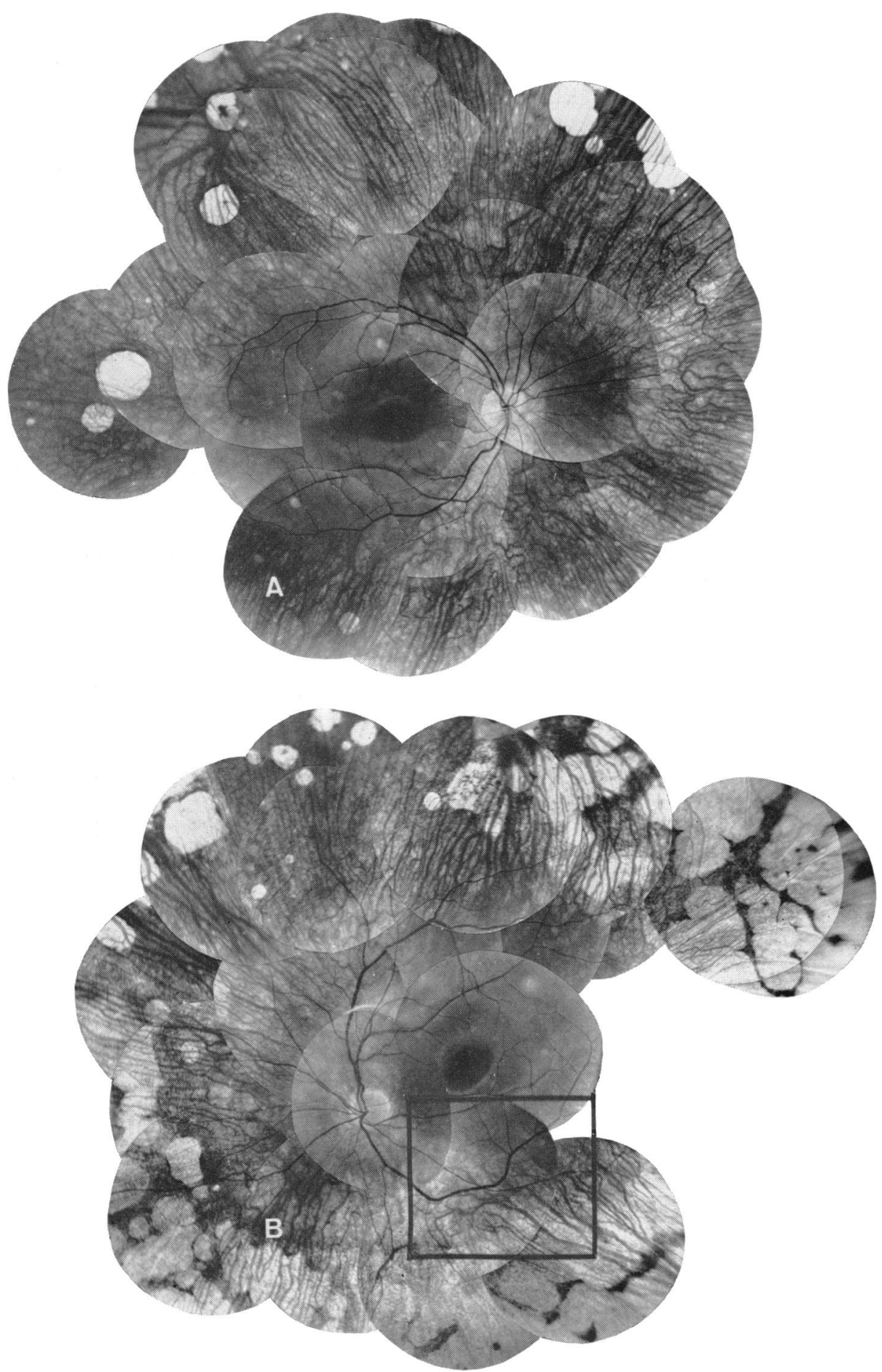

FIG. I Composite photograph of right $(\boldsymbol{A})$ and left $(B)$ posterior fundus at Stage I (Patient I). Round, separate atrophic patches of different sizes as well as fused atrophic areas of choroidal and retinal atrophy are situated in the midperiphery of the fundus. Larger choroidal vessels are visible through the translucent pigment epithelium. The disc, macula, and retinal vessels seem to be normal 

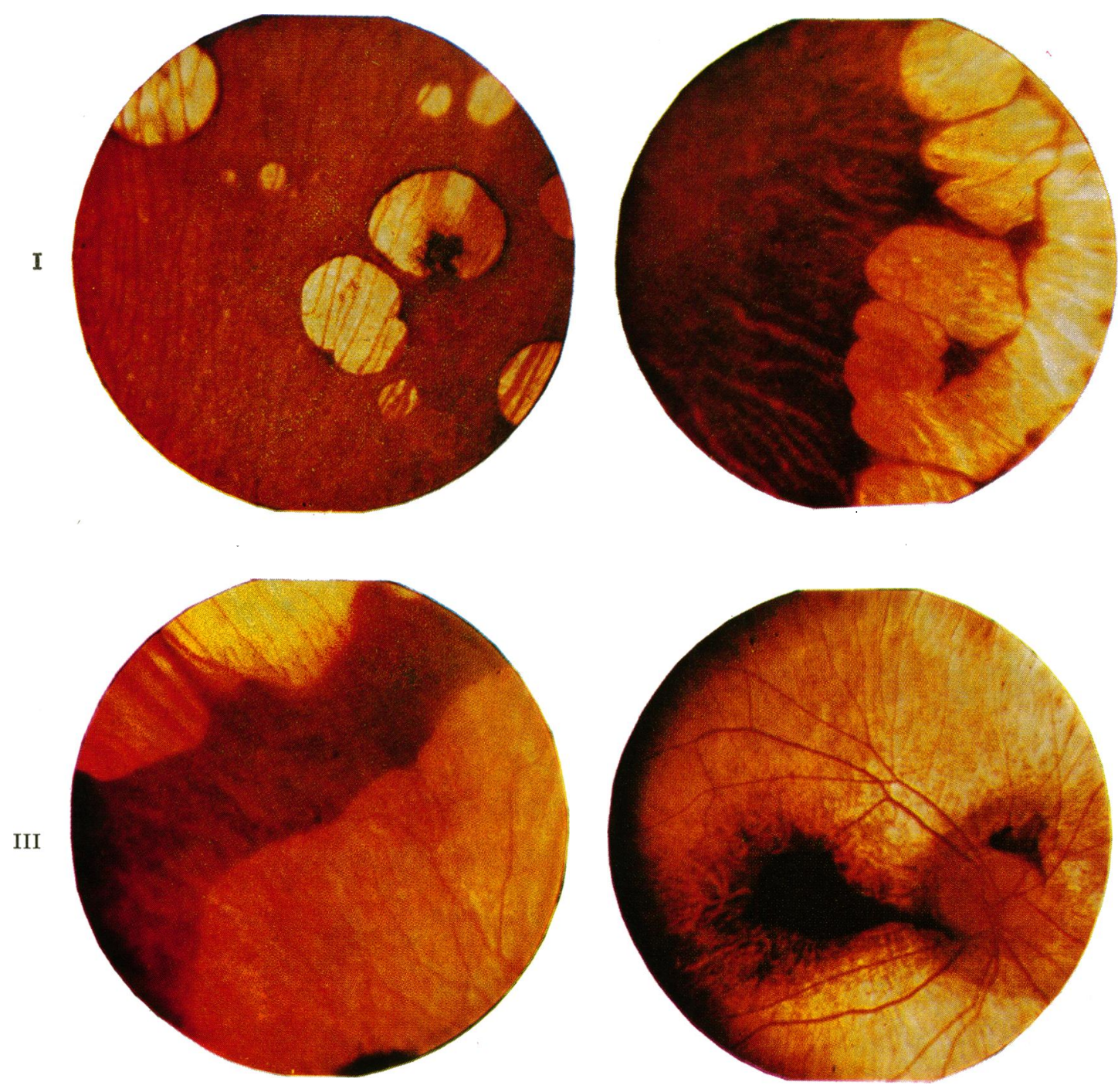

I See Fig. I A-B

III See Fig. $6 \mathrm{~A}$

II See Fig. $4 \mathrm{~A}$

IV See Fig. 7 The dark edge on the left is an artefact 


\section{Laboratory studies}

The amino-acids of plasma, urine, cerebrospinal fluid, and aqueous humour were quantitatively estimated with an automatic amino-acid analyser as described in our previous study (Simell and Takki, 1973), according to the method of Spackman, Stein, and Moore (1958). Anterior chamber puncture was used to obtain $0.15 \mathrm{ml}$. aqueous humour by a No. 4 syringe under local anaesthesia. Analysis of the basic amino-acids in the aqueous humour was performed in seven and in the cerebrospinal fluid in four patients (Table I).

The control samples of aqueous humour were obtained in the course of various ocular operations.

\section{Results}

\section{FUNDUS EXAMINATION}

The fundus changes are grouped into four stages according to progression to make discussion clearer, although no special grouping was found.

\section{Stage I}

The two youngest patients ( $\mathrm{I}$ and 2) showed a fundus periphery with sharply defined, round, separate areas of choroidal and retinal atrophy (Fig. I A-B; col. pl. I). Here and there atrophic areas were fused together and the pigment epithelium around these areas was so translucent that choroidal vessels were visible. In the yellowish-white atrophic areas, only the larger choroidal vessels were present and the blood column within these vessels seemed to have narrowed or only a white cord in place of a vessel was seen. Some pigment accumulation around the atrophic areas was seen. The disc, macular area, and retinal vessels were of normal appearance.

In the peripheral field of vision, concentric limitation of the visual fields with general diminution of light sensitivity was present in these patients, Fig. 2 A-B. In the corresponding Friedman central fields of vision only a few reduced potentials were found.

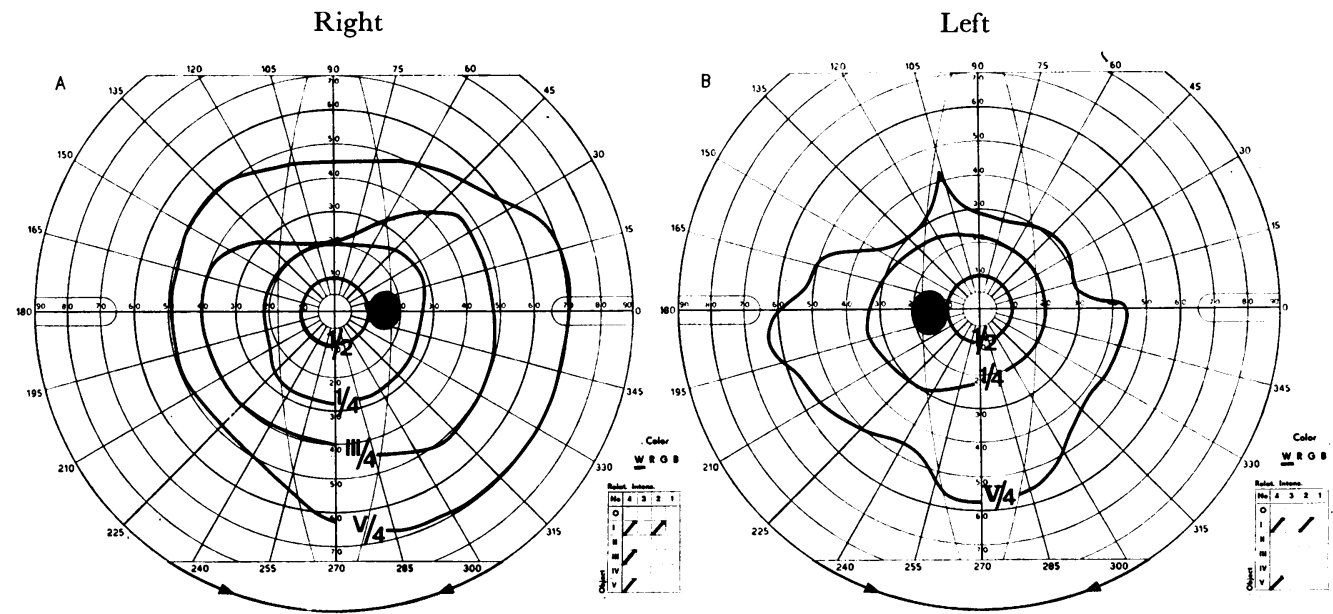

FIG. 2 Goldmann fields of vision of patient presented in Fig. I, showing typical concentric limitation

Fluorescein angiograms, taken in the area marked in Fig. I B are shown in Fig. 3 A-C. The choriocapillaris and retinal vessels seemed to fill at the same time (Fig. 3 A.). After a few seconds a demarcation line between the normal-looking area and the area of choroidal vascular atrophy was clearly visible when the dye diffused from the edge of the functioning choriocapillaris into the perivascular tissue (Fig. 3 B). A broad zone of pigmentary change was visible here. Larger choroidal vessels on the atrophic side of the demarcation line were clearly visible. At 5 minutes the dye was absorbed from the normal 


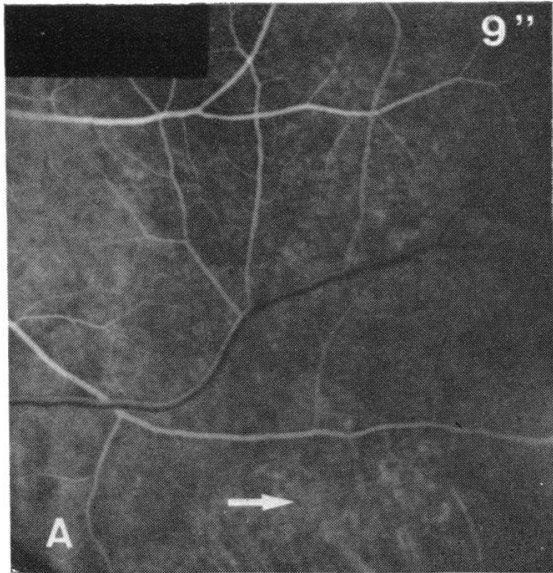

A. At the late retinal venous stage the retinal vessels appear normal and the filling of the choriocapillaris relatively even. In the zone of pigmentary changes (arrow), the choroidal fluorescence is slightly higher

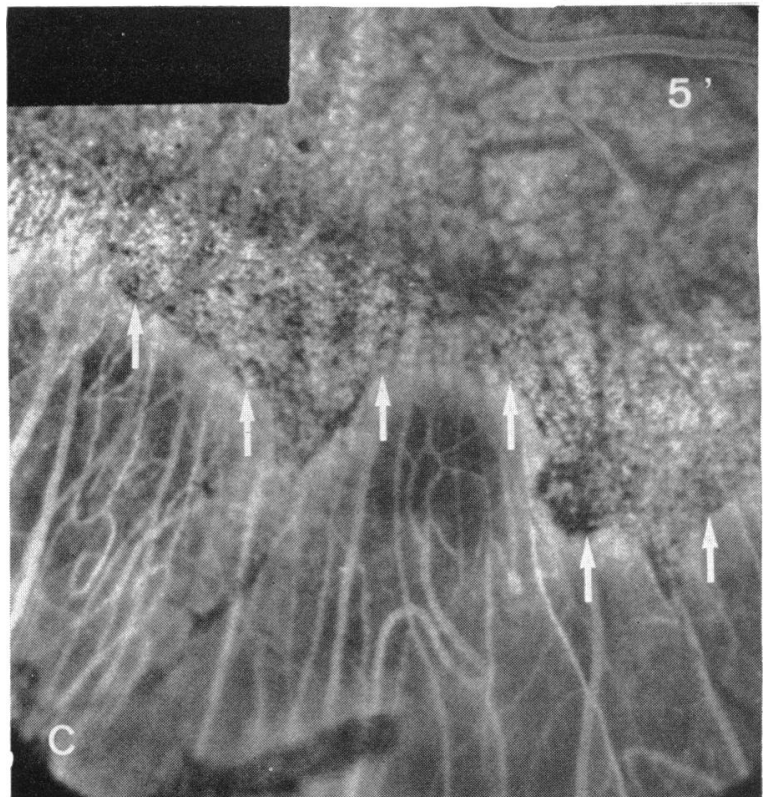

B. In the normal-looking macular area, a slight granular appearance of pigmentation becomes visible as the dye diffuses into the choroidal perivascular tissue (arrows). Between the normal retina and atrophic area there is a broad zone of pigmentary changes (segment of lines) where the dye appears in normal time sequence. In the atrophic area the large choroidal vessels have smooth contours in this young patient

C. As the dye is absorbed from the perivascular choroidal tissue, the edge between the functioning choriocapillaris and the atrophic choroid is demonstrated (arrows) more clearly than it is visible clinically

FIG. 3 Fluorescein angiograms taken in the area outlined in Fig. I B

choriocapillaris and was still present in the atrophic choroid, at which time the demarcation line between these two areas was more clearly visible than in early angiograms (Fig. 3 G). A sharply-defined atrophic picture became visible, although the change was seen clinically and in fundus photographs only as a diffuse degeneration. After 20 minutes the vessels of the retina and choroid contained no measurable amount of dye and in the atrophic area traces of dye in the inner parts of the sclera were visible. 
Stage II

With progression of the fundus changes (Patients $3,4,5$ ), the characteristic sharplydefined, garland-shaped areas of retinal and choroidal atrophy became more fused and advanced forwards to the posterior pole of the fundus (Fig. 4 A; col. pl. II). The retinal vessels were found to be narrower than at stage I and there was an area of initial degeneration around the disc.

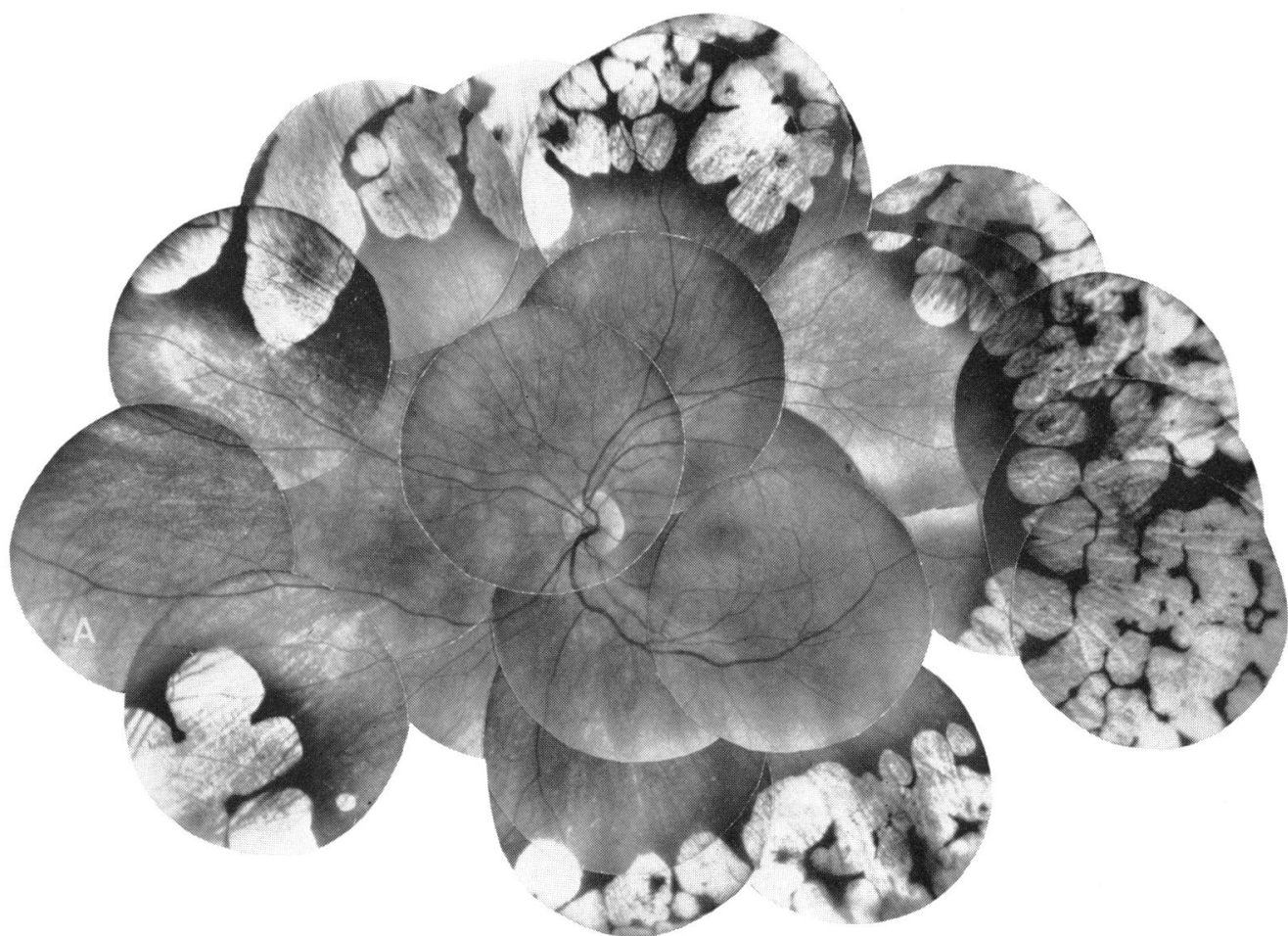

FIG. 4 A. Composite photograph at Stage II (Pat. 3). Sharply defined, garland-shaped atrophic areas have convex margins towards the posterior pole. Fine pigmentation is present around the atrophic patches in the midperiphery

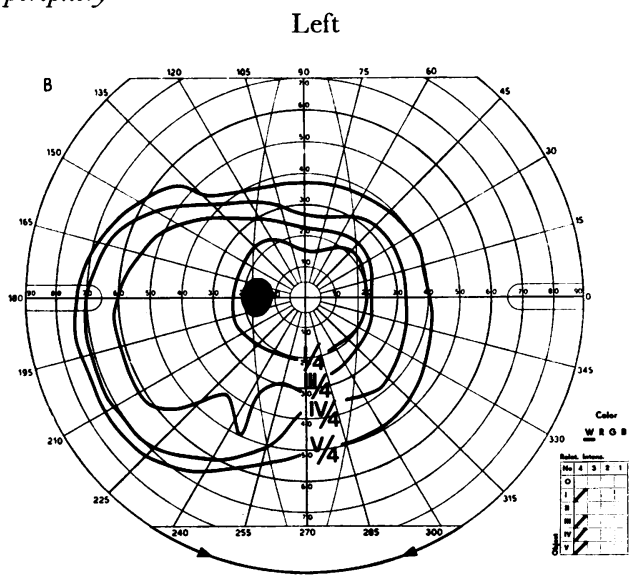

B. The corresponding Goldmann field of vision showes concentric field loss

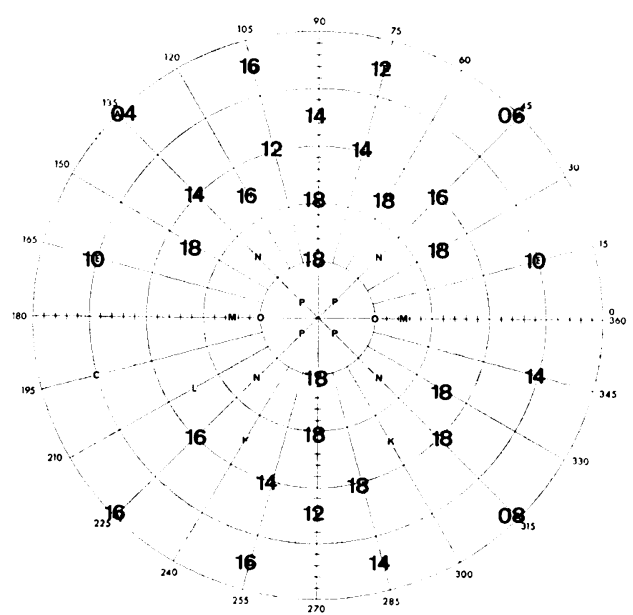

C. The Friedman field of vision discloses numerous reduced potentials 
In the peripheral fields of vision, a similar concentric limitation with diminution of light sensitivity was seen as at Stage I, but in the Friedman fields of vision more reduced potentials were found in all these patients (Fig. 4 B-C).

In fluorescein angiograms at Stage II (Fig. 5 A-D), the filling of the choroidal vessels in atrophic areas was clearly visible before any dye was present in retinal vessels. The filled choroidal vessels were wider than they seemed in the pre-injection black-and-white

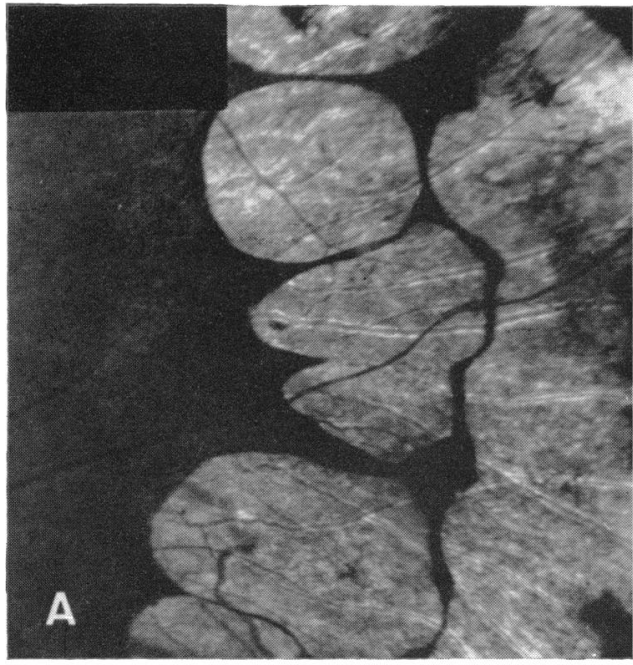

A. In the pre-injection black-and-white photograph the blood column in the choroidal vessels in the atrophic area is extremely narrow

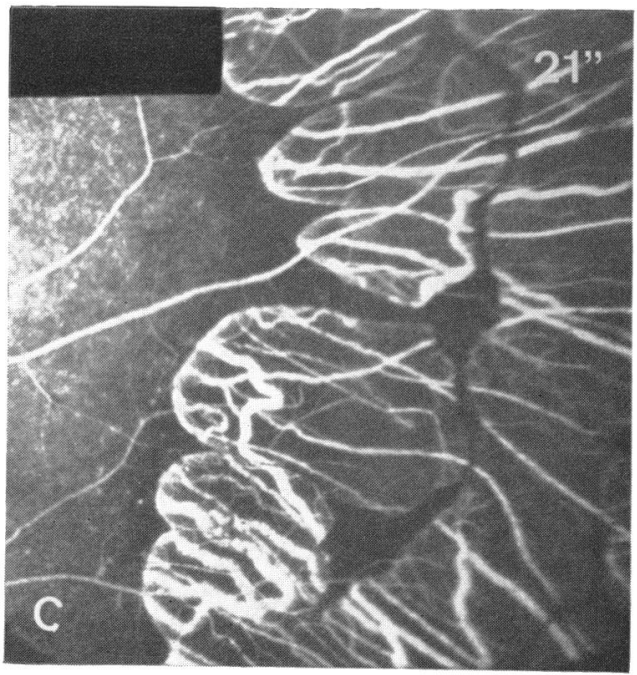

C. Diffusion of dye into atrophic choroid is sparse (arrow)

FI G. 5 Fluorescein angiograms at Stage II (Pat. 3)

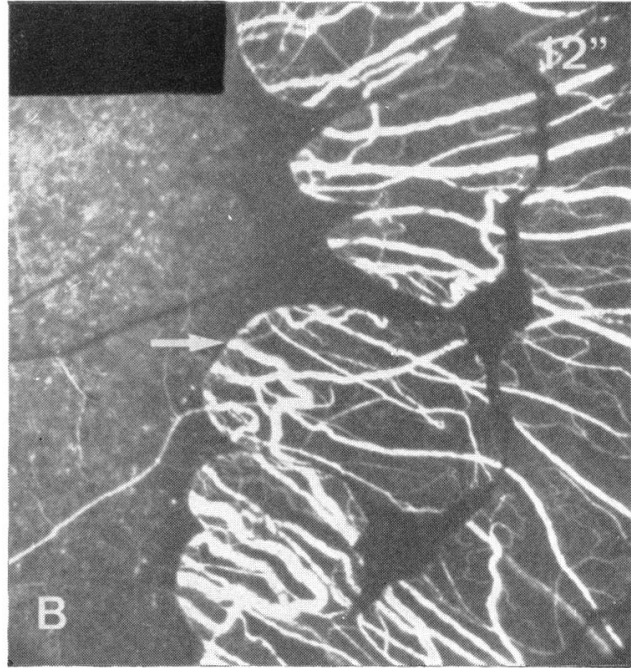

B. The blood column in the choroidal vessels appears to be much wider when the dye fills the vessels. Note that in this patient there is no transition zone of pigment changes between the normal-looking and the atrophic area (arrow)

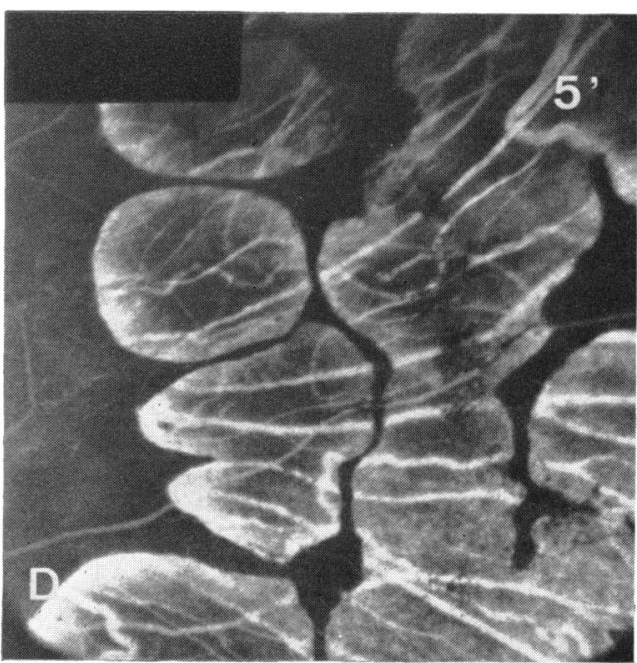

D. As the dye diffuses evenly into the atrophic patches, the pigment edges between them become clearly visible 
photographs, in which a white cord was seen at both margins of the blood column (Fig. 5 A). Around all the atrophic patches sharply-defined pigmentation was seen without any broad zone of pigmentary changes. In fluorescein angiograms of the clinically intact retina of these patients, granular filling of choriocapillaris and later diffusion of the dye out of the choriocapillaris were seen (Fig. 5 B-C). The 5-minute angiograms showed that some dye had diffused into the atrophic side of the demarcation line (Fig. 5 D).

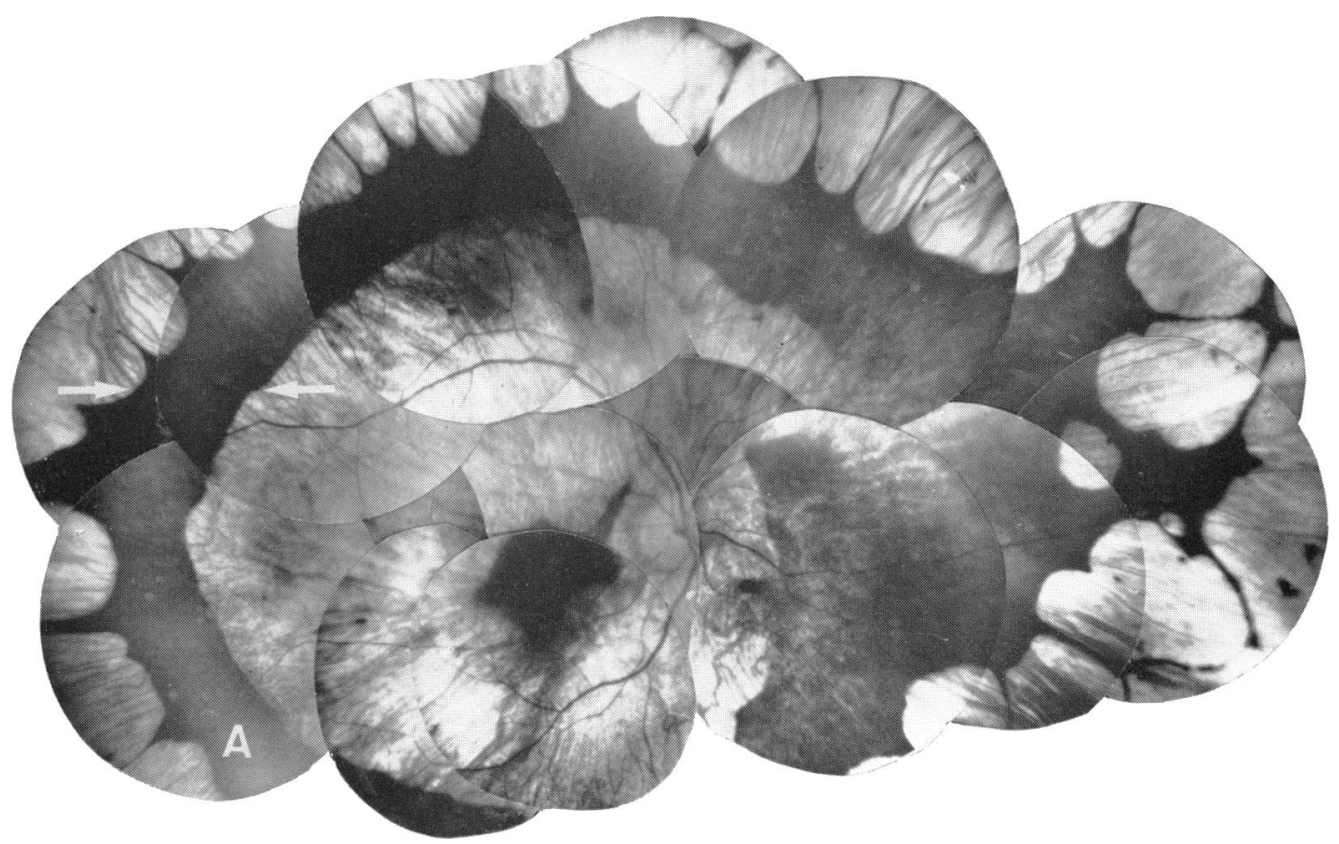

Fi G. 6 A. Composite photograph at Stage III (Pat. 8). zone of functioning retina (arrows) are features of this stage.

Large degeneration around the disc and the annular of the retina and macula

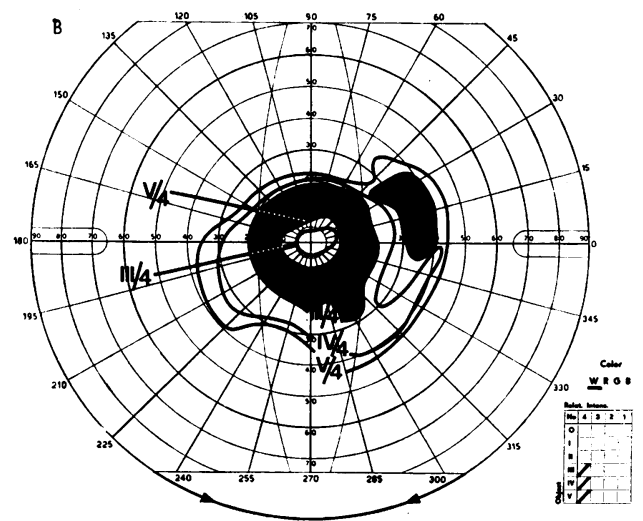

B. In the Goldmann field of vision of the same patient a ring scotoma is present corresponding to the degeneration around the disc
There is velvet-like pigmentation in the annular zone

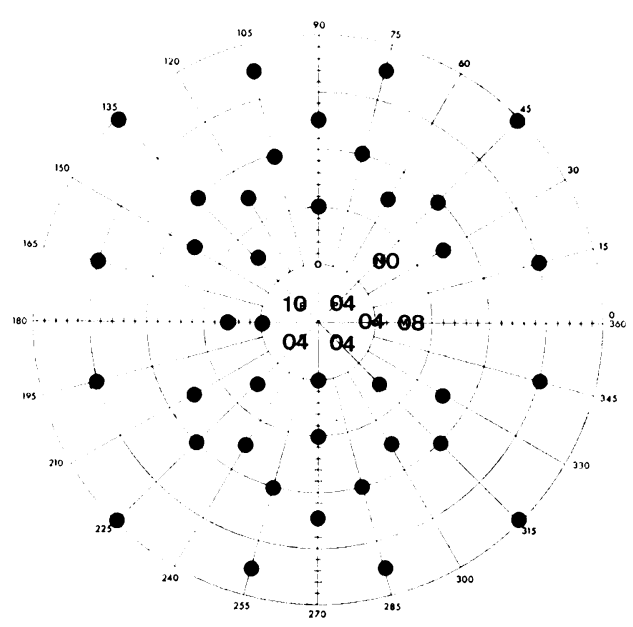

C. Only macular function is recordable in the Friedman field of vision 
Stage III

A more advanced pattern of the fundus picture was seen in Patients 7 and 8. A large degenerative area around the disc was a striking feature, and between this and the peripheral atrophic area an annular zone of functioning retina was present, as it was in the macular area. The colour of the disc seemed to be somewhat paler and the retinal vessels narrower than at the early stage of the disease. Velvet-like fine-granular pigmentation was present in the macular area, in the annular zone of retinal remnants (Fig. $6 \mathrm{~A}$; col. pl. III), and in the extreme periphery. This pigment was clearly visible in colour pictures of the fundus and in the fluorescein angiograms.

In the Goldmann fields of vision, the corresponding annular zone of retinal function was seen in addition to the minor macular function present. In the Friedman fields of vision of these patients only the macular function was detectable (Fig. 6 B-C).

In fluorescein angiograms of these patients changes similar to those at Stage II were seen, the sharp demarcation lines at each margin of the annular zone of retinal remnants being similar. The 5 -minute pictures showed diffusion of the dye into the atrophic areas on both margins of the annular zone.

Stage IV

At the late stage of the disease (Patients $9-15$ ) the whole posterior pole was atrophic, only an island of functioning macular area being present (Fig. 7; col. pl. IV). The retinal vessels were extremely narrow, the colour of the disc was pink, and the disc was not atrophic.

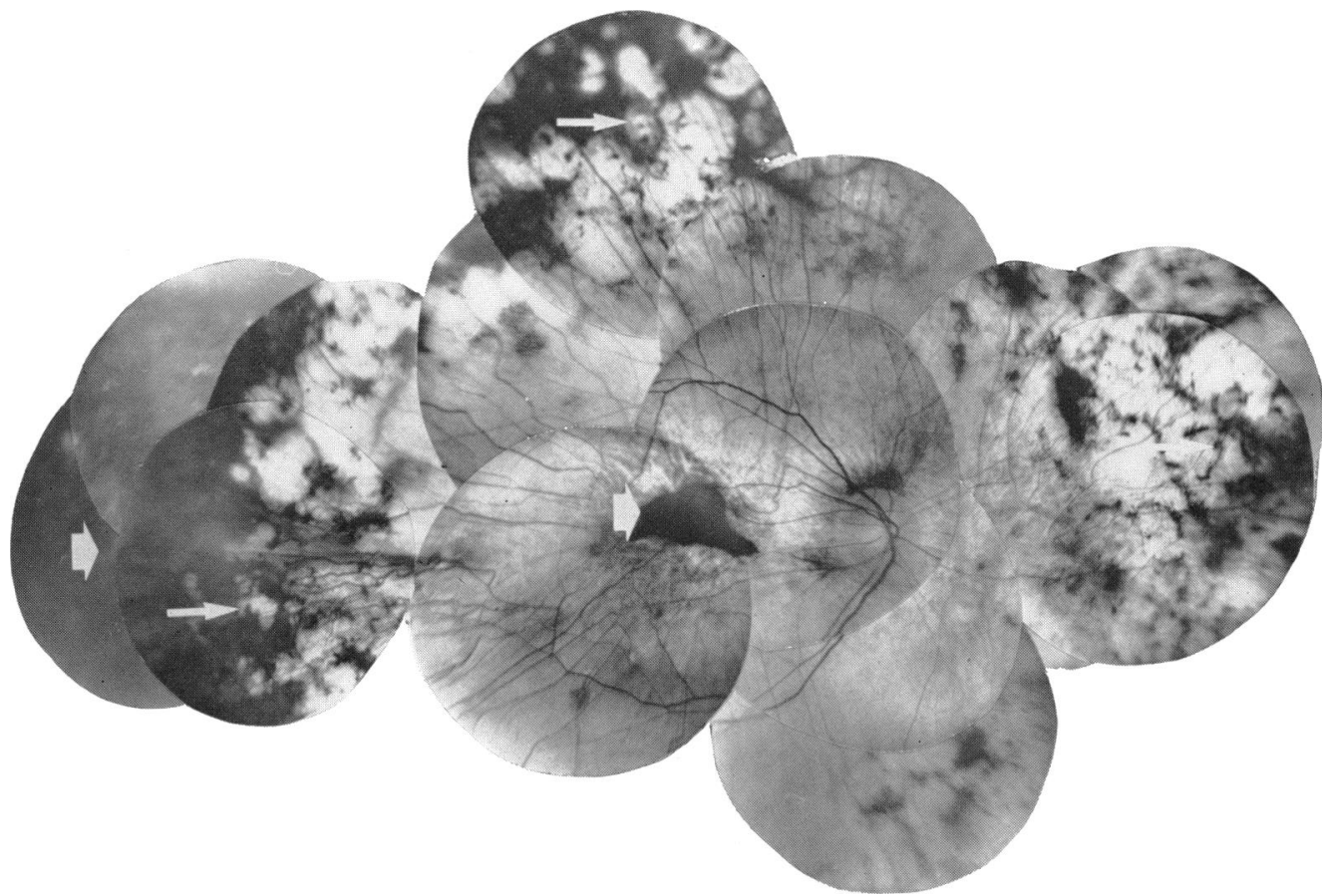

FI . 7 Composite photograph at Stage IV (Pat. I I). The whole posterior pole of the fundus is atrophic, only some functioning retina being present in the macula. Between this diffuse, large atrophic area and the equator, small round and irregular atrophic patches are seen (arrows). The velvet-like pigmentation is present (large arrows) peripheral to them as well as in the macula. On this pigment numerous crystals were noted but are not visible in the photograph. The retinal vessels are extremely narrow 
Between the equator and the ora serrata retinal tissue was also present and between this deeply pigmented retinal area and the diffuse atrophic area there were many small, round, atrophic patches like those seen in the early stages of the disease.

With progression of the disease, the velvet-like pigmentation at the equator and the macula became more dense, hiding the choroidal vessels from view. The retinal vessels were also barely visible. On the dark brown pigment numerous glittering crystals were scattered throughout the equator. The colourless, elongated, glittering crystals were clearly visible in contact lens biomicroscopy, but could not be detected in colour diapositives. The crystals were found in the fundus of Patients 6 and 9-14 and were questionable in the fundus of Patient 15 , in whom the cataract prevented visibility.

Bone corpuscle pigment typical of retinitis pigmentosa was not found in the fundus of these patients, although more granular pigmentation was seen between the atrophic patches near the equator.

Progression of the atrophic areas toward the macula was clearly seen and in some cases retinal remnants were present around the disc. At the terminal stage of the disease only a macular island of retina in the middle of the diffuse atrophic fundus was present. The chorio-retinal atrophic patches near the equator showed no tendency to progress toward the periphery.

The fundus typical of Stage IV was seen in Patients 6 and 9-15, in whom only central remnants of the field of vision were present in both the Goldmann and the Friedman perimetric studies. In the field of vision of Patient 6 some papillo-macular bundle remained in addition to macular function. In all the other patients a field of vision of under $10^{\circ}$ was seen.

In fluorescein angiographic studies at a late stage of the disease more vessels were seen than was estimated clinically (Figs $8 \mathrm{~A}-\mathrm{D}$ and $9 \mathrm{~A}-\mathrm{E}$ ). In the angiograms of the youngest patient at this stage, filling of the choriocapillaris through the velvet-like pigmentation was still visible (Fig. 8 B-C). With further progression this pigmentation was dense enough to prevent any choroidal vessels from being seen and only a few retinal vessels were visible (Fig. $9 \mathrm{~A}-\mathrm{D}$ ). The dye first appeared in the retinal vessels 9 seconds after injection. In a few seconds the demarcation line became sharply visible at the margins of the pigmented area, in which the pigment was like a fine, deep brown dust. Diffusion of the dye in the demarcation line out of the functioning choriocapillaris and later into the atrophic area was observed in the same way as at earlier stages. An abundance of fine, velvet-like pigment, sharply surrounded by the demarcation line, was seen in the 5minute angiogram (Fig. $9 \mathrm{D}$ ). The vascularity of the disc showed a normal appearance despite the wide atrophy around it (Fig. 9 E).

OTHER OPHTHALMOLOGICAL STUDIES

\section{Dark adaptation}

The different types of curves are drawn in Fig. Io. Only the youngest patient showed normal dark adaptation, while all the other patients showed a positive correlation between loss of dark adaptation and age (Fig. I I).

\section{Colour vision}

That of the six youngest patients was normal. A tritan-resembling disturbance was discovered in five patients (Fig. I2). Indefinite results were obtained in three other patients with poor visual acuity and one patient did not see the colours at all. 
$E R G$

This was examined by the routine clinical method in semi-dark-adaptation. It was extinguished in all patients studied by this method.
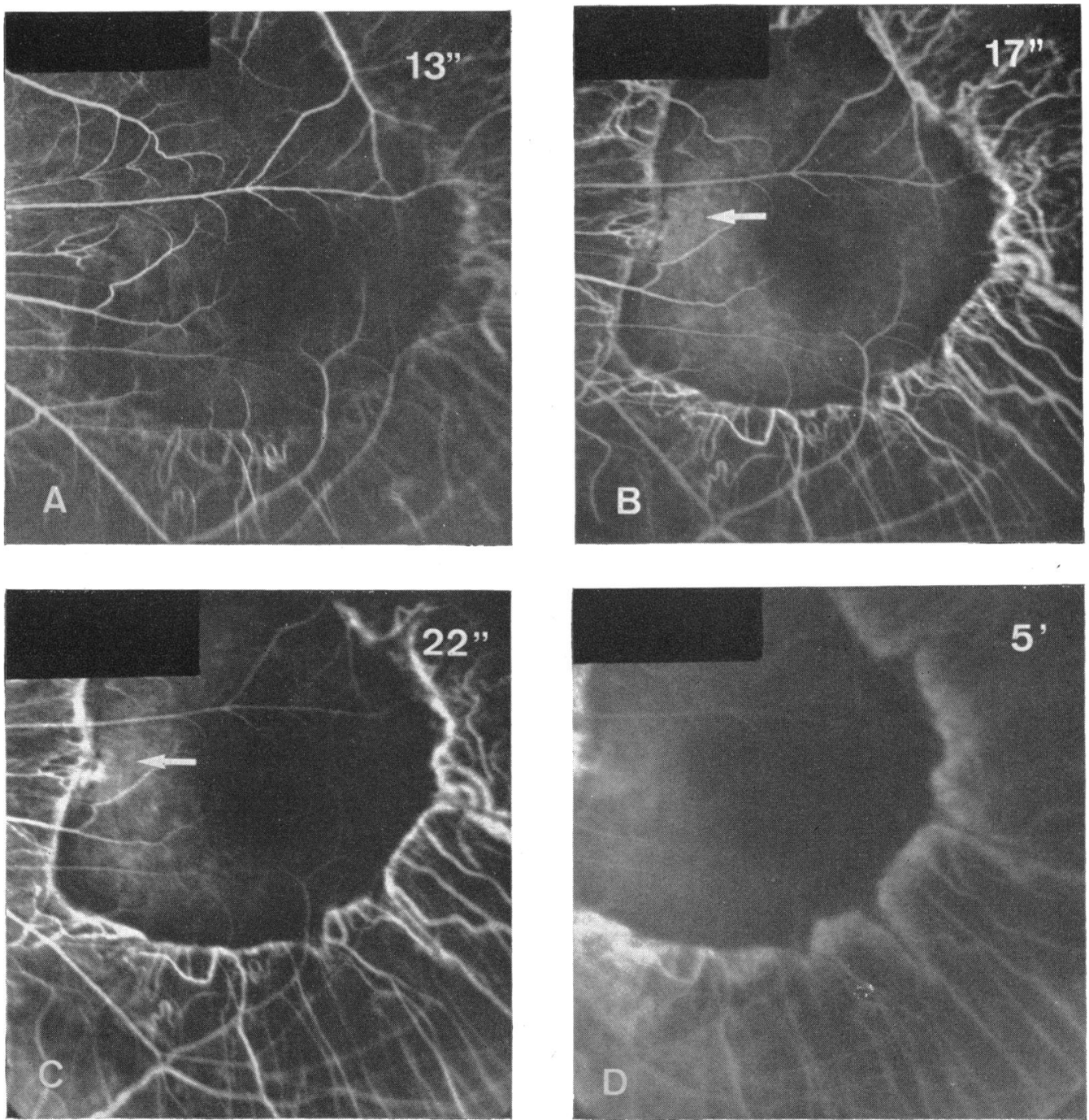

FIG. 8 Fluorescein angiograms at Stage IV (Pat. 6, 26 years)

A. The dye appears in the choroidal and retinal vessels at the same time

$\mathrm{B}$ and $\mathrm{C} . \quad$ In the functioning macular area choriocapillaris is still visible through the velvet-like pigmentation (arrow)

D. The shape of the atrophic areas become visible after diffusion of the dye into the atrophic choroid

$E O G$

This was highly abnormal in all patients. The fixation lights were seen by only seven patients in whom the ratio of peak to through voltage was highly pathological. A minimal light increase was found in only one patient with a ratio of I 25 per cent. in the right eye 

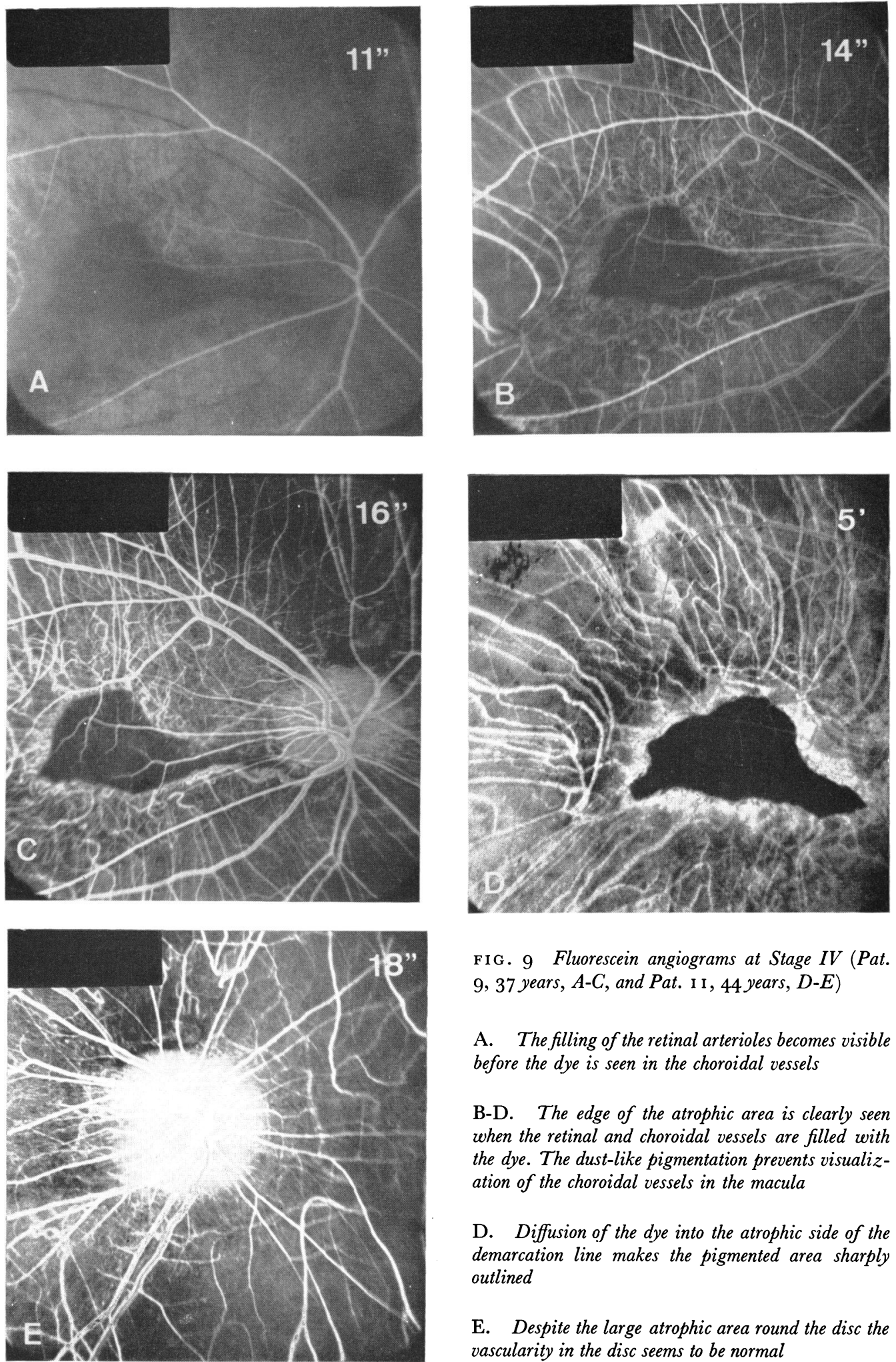

FIG. 9 Fluorescein angiograms at Stage IV (Pat. 9, 37 years, $A-C$, and Pat. I I, 44 years, $D-E$ )

A. The filling of the retinal arterioles becomes visible before the dye is seen in the choroidal vessels

B-D. The edge of the atrophic area is clearly seen when the retinal and choroidal vessels are filled with the dye. The dust-like pigmentation prevents visualization of the choroidal vessels in the macula

D. Diffusion of the dye into the atrophic side of the demarcation line makes the pigmented area sharply outlined

E. Despite the large atrophic area round the disc the vascularity in the disc seems to be normal 

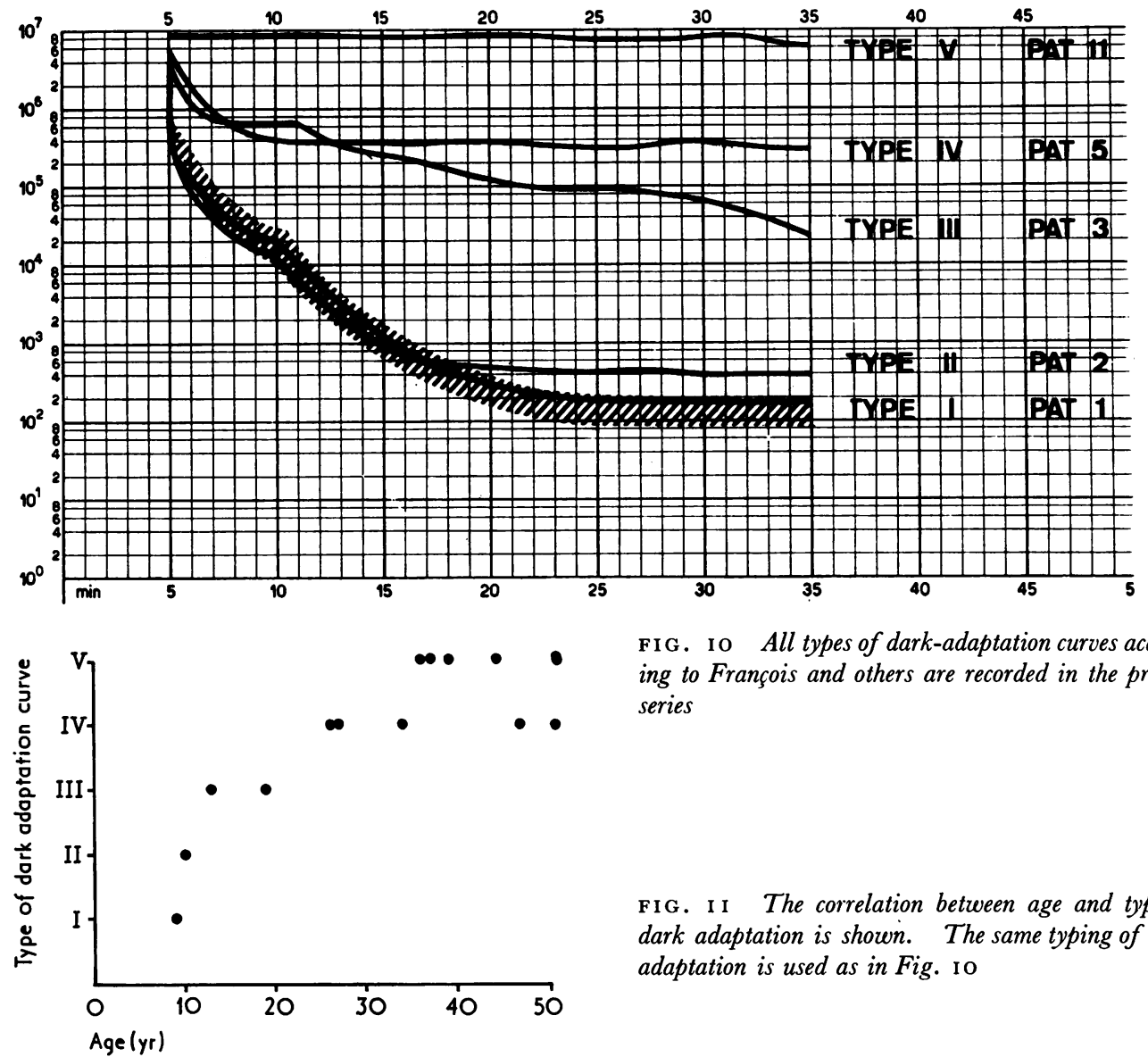

FI G. Io All types of dark-adaptation curves according to François and others are recorded in the present series

FIG. I I The correlation between age and type of dark adaptation is shown. The same typing of dark adaptation is used as in Fig. Io
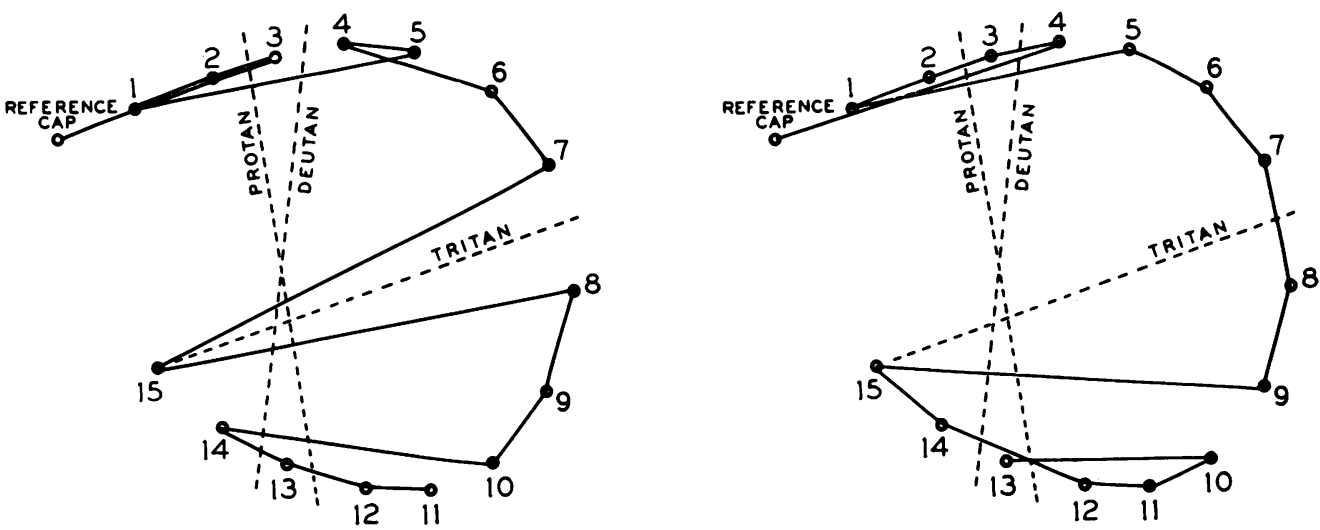

FIG. I 2 Tritan disclosed colour vision of Patient 3 . For further details see text

and 140 per cent. in the left. The ratios of the other six patients varied from 95 to i io per cent., being normally greater than 85 per cent. All patients, in whom the EOG was not recordable, showed a dark-adaptation curve of Type IV or V. 


\section{Visual acuity}

This was diminished in all patients, but they could all read something with glasses or with low-vision aids. The uncorrected visual acuity was hand movements or less in four eyes, counting fingers in 23 eyes, and 0.2 in the right and 0.15 in the left eye of the youngest patient.

\section{Refraction}

This is given in Table II as well as the visual acuity with correction. All the patients were myopes, including the aphakic patients before operation. A corrected vision of $\mathrm{I} \cdot \mathrm{O}$ was found only in three eyes.

\section{Anterior segment examination}

No specific corneal opacities were seen. There were no cells or flare in the anterior chamber or special atrophy in the iris. The colour of the irides varied in accordance with the colour of the hair. The reaction of the pupil to light was normal and no nystagmus or paresis of ocular muscles was discovered.

\section{Lenses}

Those of the two youngest patients were almost clear, showing only very thin streak-like opacities in the posterior capsules. Cataract was found in all other intact eyes and showed characteristic complications. Posterior subcapsular cataract showed a tufted character spreading in the anterior and lateral directions.

\section{Vitreous body}

Filamentous opacities were found in all patients; small punctiform opacities were present only in one (Patient 4 ).

\section{Intraocular pressure}

This was normal in $2 \mathrm{I}$ eyes in which the facility of outflow varied from 0.27 to 0.52 and the ratio of $\mathrm{Po} / \mathrm{C}$ from 22 to 38 . Patients I I to 14 were siblings, and three of them had

Table III Plasma, CSF, and aqueous humour basic amino-acid concentrations $(\mu M)$ in patients with hyperornithinaemia

\begin{tabular}{|c|c|c|c|c|c|c|}
\hline \multirow[b]{2}{*}{$\begin{array}{l}\text { Basic } \\
\text { amino-acid }\end{array}$} & \multicolumn{2}{|l|}{ Plasma } & \multicolumn{2}{|l|}{$C S F$} & \multicolumn{2}{|l|}{ Aqueous humour } \\
\hline & $\begin{array}{l}\text { Patients }(\mathbf{I} 5) \\
\text { Mean (range) }\end{array}$ & $\begin{array}{l}\text { Normal } \\
\text { adults } \\
(\text { range })^{*}\end{array}$ & $\begin{array}{l}\text { Patients }(4) \\
\text { Mean (range) }\end{array}$ & $\begin{array}{l}\text { Controls }(3) \\
\text { Mean (range) }\end{array}$ & $\begin{array}{l}\text { Patients }(7) \\
\text { Mean (range) }\end{array}$ & $\begin{array}{l}\text { Controls }(4) \\
\text { Mean (range) }\end{array}$ \\
\hline Ornithine & $\begin{array}{l}\text { I } 069^{\circ} 0 \\
\left(79^{\circ} \cdot 0-\mathbf{1} 339^{\circ} 0\right)\end{array}$ & $30-64$ & $\begin{array}{l}288 \cdot 2 \\
(240 \cdot 3-313 \cdot 7)\end{array}$ & $\begin{array}{l}8 \cdot 1 \\
(5 \cdot 7-10 \cdot 9)\end{array}$ & $\begin{array}{l}897 \cdot 6 \\
(763 \cdot 2-986 \cdot 7)\end{array}$ & $\begin{array}{l}62 \cdot 7 \\
(37 \cdot 8-83 \cdot 8)\end{array}$ \\
\hline Lysine & $\left(\begin{array}{l}76 \cdot 6 \\
\left(5^{0} \cdot 8-\text { Iоo-2 }\right)\end{array}\right.$ & $105^{-207}$ & 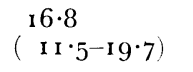 & $\begin{array}{l}26 \cdot 1 \\
(15 \cdot 7-44 \cdot 3)\end{array}$ & $\begin{array}{l}8 \mathbf{I} \cdot 5 \\
(73 \cdot 4-9 \mathbf{I} \cdot 7)\end{array}$ & $\begin{array}{l}\text { I } 45 \cdot 0 \\
(128 \cdot 4-158 \cdot 4)\end{array}$ \\
\hline Histidine & $\begin{array}{l}8 \mathrm{I} \cdot 8 \\
(69 \cdot \mathrm{I}-\mathrm{I} 07 \cdot 5)\end{array}$ & $32-97$ & $\left(\begin{array}{l}\text { I9.I } \\
(10 \cdot 5-33 \cdot 7)\end{array}\right.$ & $\begin{array}{l}\text { I } 9 \cdot 2 \\
(\text { I } 3 \cdot 0-29 \cdot 8)\end{array}$ & $\left(\begin{array}{l}95 \cdot 6 \\
70 \cdot 6-\text { I I } 6 \cdot 0\end{array}\right)$ & $\begin{array}{l}6 I \cdot 4 \\
(50 \cdot 3-7 I \cdot I)\end{array}$ \\
\hline Arginine & $\left(\begin{array}{l}86 \cdot 9 \\
54 \cdot 7-\operatorname{III} \cdot 7)\end{array}\right.$ & $40-140$ & $\left(\begin{array}{l}25 \cdot 7 \\
(19 \cdot 8-32 \cdot 9)\end{array}\right.$ & $\begin{array}{l}28 \cdot 3 \\
(20 \cdot 6-43 \cdot 7)\end{array}$ & $\left(\begin{array}{l}93 \cdot 8 \\
\left(69 \cdot 5^{-1} 17 \cdot 5\right)\end{array}\right.$ & $\begin{array}{l}\text { I } 89 \cdot 3 \\
(88 \cdot 9-130 \cdot 6)\end{array}$ \\
\hline
\end{tabular}

\footnotetext{
* Soupart (1962)
} 
open-angle glaucoma well controlled. The fourth of these siblings had intraocular pressures and tonographic values within normal limits.

\section{LABORATORY FINDINGS}

The plasma ornithine concentration in all patients had increased 10 to 20-fold in comparison with the normal level (Table III). The ornithine concentration of the aqueous humour and cerebrospinal fluid had increased similarly. The concentration of the other amino-acids was normal in all samples. The basic amino-acids are given in Table III. The urine showed a typical overflow aminoaciduria, with an increase in ornithine only. The distribution of ornithine concentration according to age is given in Fig. I3. No positive correlation of age or of severity of choroidal atrophy with ornithire concentration was found.

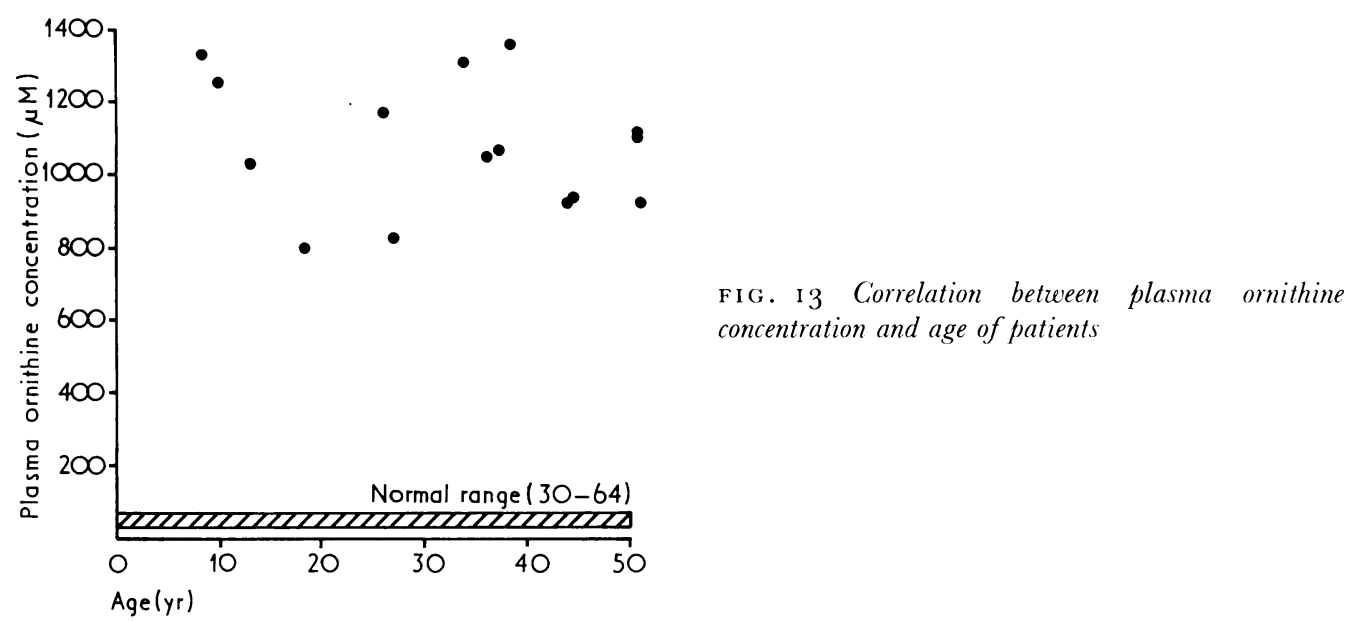

The following laboratory tests gave normal results for all patients: haematological examination, serum electrolytes, calcium, inorganic phosphate, alkaline phosphatase, blood sugar, serum proteins, serum protein electrophoretic pattern, serum aspartate, aminotransferase, alanine aminotransferase, aldolase, ornithine carbamylphosphate transferase, creatinine, protein-bound iodide, $\mathrm{aVT}_{4}$, capillary $\mathrm{pH}$, and urine analysis. The blood ammonia concentration, determined both postprandially and after l-alanine and ammonium lactate loads, was not increased.

The skull and thorax $x$-rays and the electrocardiograms were normal.

OTHER CLINICAL ASPECTS (Table IV)

There were usually no abnormalities in the histories of the patients, although two of them did not get beyond elementary school (Pat. 5 and 13 ). Convulsions were observed in the course of 2 years in two patients ( 5 and 10 ), although neither of them needed any treatment at the time of the study. Two patients ( 10 and I I) had been treated for insomnia at some time in the last 8 years. One of the patients (5) was in a supervised work centre and another (13) was looked after by a guardian at home.

The electroencephalogram results are shown in Table IV. The EEG was normal in four patients. In five cases borderline EEGs with a slight increase in theta-activity $\left(4^{-} 7 \mathrm{~Hz}\right)$ in the temporal or occipital regions were recorded. In one case possible but not certain sharp waves in the right fronto-temporal region were observed during drowsiness. 
Table IV Electroencephalography (EEG), intelligence quotient (IQ), audiogram, and electronystagmography $(E \mathcal{N} G)$, and other special features

\begin{tabular}{|c|c|c|c|c|c|}
\hline $\begin{array}{l}\text { Pat. } \\
\text { no. }\end{array}$ & $E E G$ & $I Q$ & Audiogram & $E \mathcal{N} G$ & Special features \\
\hline I & Abnormal & 120 & Normal & Normal & Shrill voice \\
\hline 2 & $\begin{array}{l}\text { Slightly } \\
\text { abnormal }\end{array}$ & 89 & Normal & Normal & \\
\hline 3 & $\begin{array}{l}\text { Slightly } \\
\text { abnormal }\end{array}$ & 86 & Normal & & \\
\hline 4 & Normal & 72 & Normal & & $\begin{array}{l}\text { Unable to attend } \\
\text { regular school }\end{array}$ \\
\hline 5 & Normal & 53 & Normal & & $\begin{array}{l}\text { Convulsions for } 2 \text { years } \\
\text { (1 } 957-59) \\
\text { In a supervised work centre }\end{array}$ \\
\hline 6 & Borderline & 93 & Normal & & \\
\hline 7 & Abnormal & 115 & $\begin{array}{l}\text { Slightly reduced sensory } \\
\text { hearing in left ear }\end{array}$ & & \\
\hline 8 & Normal & 103 & Normal & & \\
\hline 9 & Borderline & 94 & Normal & & \\
\hline 10 & Borderline & 96 & Normal & Normal & $\begin{array}{l}\text { Convulsions in } 1965-69 \\
\text { Diazepam-treatment for } \\
\text { insomnia }\end{array}$ \\
\hline I I & Borderline & 96 & Normal & & $\begin{array}{l}\text { Promethazine and barbiturate } \\
\text { treatment for last } 8 \\
\text { years for insomnia }\end{array}$ \\
\hline 12 & Abnormal & 109 & $\begin{array}{l}\text { Slightly reduced sensory } \\
\text { hearing in left ear }\end{array}$ & Normal & \\
\hline 13 & Normal & 76 & $\begin{array}{l}\text { Slightly diminished hearing } \\
\text { in each ear }\end{array}$ & Normal & $\begin{array}{l}\text { Did not progress beyond } \\
\text { elementary school } \\
\text { Now under a guardian }\end{array}$ \\
\hline 14 & & & $\begin{array}{l}\text { Slightly diminished hearing } \\
\text { in each ear }\end{array}$ & & \\
\hline I 5 & Borderline & 99 & Normal & Normal & \\
\hline
\end{tabular}

The EEG was rated slightly abnormal in two patients, in both of whom the activity was slightly slow for the age (7-8 and 6-9 Hz.) In one (3) the activity was monotonously rhythmical in all regions and the other (2) showed generalized slow wave (theta) paroxysms without drowsiness.

In three cases the EEG was moderately abnormal with focal abnormalities. Two patients showed an increase in irregular theta-waves and periods of regular theta-activity in the temporal regions. During drowsiness, the first of these (7) had paroxysms of slow waves $(2-4 \mathrm{~Hz})$ predominantly over the left hemisphere and the other (I2) sharp and slow wave complexes in the right temporal region. In the third ( $\mathrm{I})$ there were focal sharp waves in the left rolandic region.

Thus the EEG was slightly to moderately abnormal in five of the fourteen patients. Pathological activity consisted of an increase in slow activity, focal slow-wave abnormalities, and/or focal sharp waves. Photic stimulation and overventilation did not provoke pathological activity but drowsiness activated the focal abnormalities.

Neurological and medical examination revealed no special abnormalities. 
The results of the audiological examination are also listed in Table IV. In eleven patients the audiogram was normal. Hearing was slightly reduced in each ear in two patients ( 13 and 14) and in one ear in two other patients (7 and 12).

An electronystagmograph was taken of six patients. None showed anything pathological (Table IV).

Psychological tests were performed on fourteen patients (Table IV). In eleven the intelligence quotient (IQ) was normal. Slight retardation (IQ 53) was found in one patient and subnormal intelligence (IQ 72-85) in three.

\section{Discussion}

In our previous study we showed a constant relationship between hyperornithinaemia and gyrate atrophy of the choroid and retina (Simell and Takki, I973). Six additional patients showed similar hyperornithinaemia with gyrate atrophy of the choroid and retina in the present study, which suggests an inborn error of amino-acid metabolism in patients with this ophthalmic disease. Moreover, our preliminary estimation of the enzyme activities of liver biopsy in these patients revealed a defect in enzyme ornithineketoacid aminotransferase (OKT) (Takki and Simell, to be published). Therefore the raised plasma ornithine concentration connected with gyrate atrophy of the choroid and retina offers a possibility for delineation of a new entity.

In the present study all the patients with gyrate atrophy of the choroid and retina showed typical signs of a diffuse total choroidal vascular atrophy, which has been described as pathognomonic in this disease (Krill and Archer, I97 I). According to an earlier opinion (Botermans, 1972), the atrophic patches in the fundus of this disease start in the equatorial region and spread both centrifugally and centripetally. In the present series only a centripetal spreading of the atrophic patches was seen. This depends on the fact that the small atrophic patches initially found (Stage I) in the equatorial region are still detectable unchanged at a late stage of the disease (Stage IV), situated between the diffuse atrophic area and the velvet-like pigmentation peripheral to them.

The peculiar fine pigmentation, described earlier by Kurstjens ( I 965), increases during the progression of the disease. It is especially marked in Stage III and IV in the macula and periphery, where it hides all the ocular tissues beneath from view. On this pigmentation, numerous elongated glittering crystals were seen. The typical spreading of the disease and the velvet-like pigmentation with glittering crystals offer a good clinical method of differentiating gyrate atrophy of the choroid and retina from the other primary choroidal atrophies. The facts concerning the differential diagnosis of gyrate atrophy of the choroid and retina are described in detail elsewhere (Takki, I974).

In fluorescein angiographic studies, changes in the pigment of the pigment epithelium modify the underlying fluorescence (Amalric, I969; Archer, Krill, and Newell, I970; Hyvärinen, Maumenee, Kelley, and Cantollino, I97 I Vannas, Raitta, and Vannas, I97 I ; Archer, 1972; Shakib, Rutkowski, and Wise 1972).

The pigment changes are clearly seen in fluorescein angiograms in the present series. At the early stage of the disease a broad zone of destruction in the pigment epithelium in the border of an atrophic area is visible and in the 5-minute angiograms the typical, sharplydefined figure of gyrate atrophy is seen when the dye has been absorbed from the perivascular space. These changes are advanced farther towards the normal-looking retina than was clinically expected, thus indicating an extensive change in the pigment epithelium. However, changes in the pigment epithelium in the fluorescein angiograms are not necessarily associated with the function of the pigment epithelium (Archer, 1972). 
At the late stage of the disease the velvet-like dispersed pigment is gathered into the macular area and periphery. This pigment is sharply distinguished from the surrounding atrophic area in fluorescein angiograms.

At the late stage of the disease extensive attenuation of retinal vessels is observed by ophthalmoscopy, although in angiograms the vessels appear wider. The vascularity at the papilla seems to be normal and on the other hand the maculo-papillary bundle in the visual field studies was found to persist late in the disease. According to these facts the involvement of the layer of the ganglion cells is a late affection of the retinal layers.

The electroretinogram records rapid alterations in retinal nervous activity in bipolar and receptor cell layers, whereas the electro-oculogram is concerned with slower changes in potential, which occur as a result of alterations in the metabolism of the pigment epithelium (Arden and others, 1962). The method of the ERG examination used in the present study does not serve for differentiation of the function of cones and rods. In this study the ERG was extinguished in all cases. However, the dark-adaptation curves showed progression of the disease with age, which indicates progressive lesions in the rods. The colour vision in the six youngest patients was normal and disturbances in colour vision were found only in association with impaired visual acuity. This means that cone function is spared until the late stage of the disease.

The EOG was highly pathological in all patients, indicating disturbance in the pigment epithelium in the early stage of the disease. Changes in fluorescein angiograms and in the EOG suggest that the primary lesion is at the level of pigment epithelium-the choriocapillaris and other ocular tissues suffering from secondary atrophy while the cones are more resistant.

In the present study hyperornithinaemia was found without hyperammonaemia. A similar picture of pathological findings has been described only by Bickel, Feist, Müller, and Quadbeck ( 1968 ) in two patients, 3- and 7-year-old sisters, who had a slightly elevated concentration of ornithine $\left(15 \mathrm{I}^{\cdot} 3\right.$ and $196 \cdot 7 \mu \mathrm{M}$ ) due to decreased activity of OKT (Kekomäki, Räihä, and Bickel, I969). Despite hyperornithinaemia and the OKT deficiency, the patients revealed a generalized aminoaciduria and mental retardation with normal funduscopic findings. Furthermore, data on only one patient with a highly elevated plasma ornithine concentration $(9 \mathrm{I} 5 \mu \mathrm{M})$ comparable to the present series has been published (Shih, Efron, and Moser, I 969). Yet this 3-year-old boy also had hyperammonaemia and homocitrullinuria combined with psychomotor retardation, infantile spasms, irritability, and intermittent ataxia; the ophthalmic findings were not reported. In the present series only one out of fifteen patients showed slight signs of mental retardation, which however may depend on the other diseases diagnosed in his family. The other patients in this series were mentally clear. It therefore seems justified to assume that the present syndrome is different from that described by Bickel and others (1968) or Shih and others (1969) and has not been defined earlier.

The connection between the impaired ornithine metabolism and gyrate atrophy of the choroid and retina is not known. The chorio-retinal degenerations in these patients develop progressively and the plasma ornithine concentration is already high at an early stage of the disease. The ocular changes may depend on a direct toxicity of ornithine or its metabolites in the eye, or on an indirect cause by which one of these alters some reaction in the chorio-retinal tissues. The direct toxicity of ornithine or one of its metabolites hardly seems evident, since no correlation between the degree of the ocular changes and plasma ornithine concentration of these patients was found. On the other hand, an indirect mechanism, modifying some ocular reaction with an excess of ornithine or of some of its 
metabolites, seems more probable. This possibility is also supported by the results of François (1964), which suggested that the origin of the tapeto-retinal degenerations in mice resulted from an abnormality in the synthesis of protein in the external layers of the retina. The presence of opsin with a normal structure also seems to be necessary for the formation of visual purple (Dowling and Wald, i960).

Myopia, complicated cataract, vitreous opacities, concentric limitation of the field of vision, and abnormalities in the ERG, EOG, and dark adaptation, with typical changes in the fundus, are constant ophthalmological features of these fifteen patients with gyrate atrophy of the choroid and retina and hyperornithinaemia. Glaucoma is present only in one family and cannot be regarded as a feature of this disease.

In conclusion, it must be pointed out that the constant co-existence of hyperornithinaemia with gyrate atrophy of the choroid and retina offers a new and excellent method of confirming the diagnosis of this disease.

\section{Summary}

A detailed ophthalmological examination was performed on fifteen patients with gyrate atrophy of the choroid and retina. The fundus changes were grouped into four stages according to the progression of the disease. The youngest patients (Stage I) showed round, separate, or fused atrophic areas in the midperiphery of the fundus. In fluorescein angiographic studies a broad zone of pigmentary changes was observed between the normallooking and the atrophic areas. At Stage II the atrophic areas became more fused and advanced toward the posterior pole and a sharply-defined demarcation line between the normal-looking and atrophic area was seen in fluorescein angiograms. At Stage III a large degenerative area around the disc was seen and at Stage IV all of the posterior pole except for the macula was atrophic. Around the atrophic areas fine pigmentation was detected. With the progression of the disease, an abundance of this fine, dense, velvetlike pigment was seen in the macula and peripheral retina. At the late stage the pigmentation hid all the choroidal vessels from view. Colourless, elongated, glittering crystals were found on the fine pigmentation in this study during contact lens biomicroscopy.

The primary site of the lesion in this disease is thought to be at the level of the pigment epithelium - choriocapillaris, because the EOG was highly pathological in all patients and marked changes were visible in fluorescein angiograms. The dark-adaptation curves showed a progressive lesion in rod function. The cone function was spared even late in the disease, as seen in colour vision studies.

Myopia and complicated cataract were present in all patients. Patients with gyrate atrophy of the choroid and retina had an increased plasma, cerebrospinal fluid, and aqueous humour ornithine concentration, which was ten to twenty times higher than normal.

Defective activity of the enzyme ornithine ketoacid aminotransferase is probably the origin of this inborn error of amino-acid metabolism.

I should like to thank Prof. Salme Vannas, M.D., for referring one patient with gyrate atrophy of the choroid and retina, Docent Märta Donner, M.D., for carrying out the neurological examinations, the psychologists at the Children's Clinic and Institute of Occupational Health, and the audiologists at the Department of Oto-rhino-laryngology, University of Helsinki.

This study was supported by grants from the Sigrid Juselius Foundation and from Kaukomarrkkinat Oy. 


\section{References}

Amalric, P. (1969) Bull. Soc. Ophtal. Fr., numéro spécial, p. I89 ARChER, D. B. (1972) In "Hereditary Retinal and Choroidal Diseases", vol. I Evaluation, ed. A. E. Krill, p. 73. Harper and Row, Hagerstown, Md.

, KRILl, A. E., and NeWell, F. W. (1970) Amer. F. Ophthal., 69, 543

ARden, G. B., BARRAdA, A., and kelsey, J. H. (1962). Brit. F. Ophthal., 46, 449

BEGKER, B., and SHAFFER, R. N. (1970) "Becker-Shaffer's Diagnosis and Therapy of the Glaucomas", 3rd ed., ed. A. E. Kolker and J. Hetherington, p. 3. Mosby, St. Louis

BICKEL, H., FEIST, D., MÜLleR, H., and QUADBECK, G. (1968) Dtsch. med. Wschr., 93, 2247

вотERMANS, с. н. G. (1972) "Neuroretinal degenerations", in "Handbook of Clinical Neurology", vol. I3, ed. P. J. Vinken and G. W. Bruyn, pp. 253, 256. North Holland Publishing, Amsterdam DOWLING, J. E., and WALD, G. (1960) Vitam. and Horm., 18, 515

FIEANDT, K. von, and кALIMo, E. (eds) (I972) WAIS, Wechslerin aikuisten alykkyysasteikko. David

Wechsler, vakaamisen ja käsikirjan laatimisen Suomen oloihin suorittaneet K. von Fieandt ja

E. Kalimo. Psykologien kustannus Oy, Helsinki

FRANCESGHETtI, A., FRANÇOIS, J., and BABEL, J. (1963) "Les hérédodégénérescences chorio-rétini-

ennes", vol. 2, p. 647 . Masson, Paris

FRANÇOIS, J. (1964) Exp. Eye Res., 3, 405

——_ VERriest, G., and DE ROUCK, A. (1956) "Les fonctions visuelles dans les dégénérescences

tapéto-rétiniennes", Ophthalmologia (Basel), 131, Suppl. 43

hyVärinen, L., maumenee, A. e., Kelley, J., and cantollino, s. (197i) Amer. F. Ophthal., 71, i 7

KARPE, G. (I962) In "Ist Symp. ISCERG, Stockholm, I96I", ed. G. Karpe, Acta ophthal. (Kbh.),

Suppl. 70, p. I5

KeKомӓкI, м. P., RÄIHё, N. C. R., and bickel, H. (I969) Clin. chim. Acta, 23, 203

KRILl, D. E., and ARGHER, D. (I97I) Amer. F. Ophthal., 72, 562

KURSTJENS, J. H. (1965) Docum. ophthal. (Den Haag), 19, I

moSes, R. A., and BeCKer, B. (1958) Amer. F. Ophthal., 45, I96

pampiglione, G. (1956) Proc. electro-physiol. Technologists' Ass., 7, I

SHAкiв, м., RUtкowski, P., and wise, G. N. (1972) Amer. F. Ophthal., 74, 206

Shih, v. e., efron, m. L., and moser, h. w. (r969) Amer. F. Dis. Child., r17, 83

SIMELl, O., and TAKKI, K. (1973) Lancet, I, IO3 I

soupart, P. (1962) In "Amino Acid Pools", ed. J. T. Holden, p. 233. Elsevier, Amsterdam

SPACKman, D. H., stein, w. H., and moore, s. J. (1958) Analyt. Chem., 30, I 190

TAKKI, K. (1974) Brit. F. Ophthal., 58, 24

vannas, s., Raitta, c., and vannas, A. (I97 I) In "Proc. int. Symp. Fluorescein Angiography, Albi, r969", ed. P. Amalric, p. I69. Karger, Basel

WECHSLER, D. (1949) "Weschsler Intelligence Scale for Children. Manual". Psychological Corporation, New York 